\title{
Madagascar's future climate change intensified actions and policy reforms: fostering local initiatives or business as usual?
}

\author{
Jean-Roger Mercier', Yasmin Meraliı
}

\author{
Correspondence: \\ CyberOustal, France \\ E-mail: jeanrogermercier@yahoo.fr
}

\begin{abstract}
As Madagascar, like all other countries on the globe, is gearing up for the meeting of the 21st Conference of Parties (COP21) of UN's Framework Climate Change Convention (UNFCCC), we reflect on the persistent failure of development policies in Madagascar, and suggest that there may be fundamental flaws in perceptions about development interventions and transferability of solutions, resulting in a country in permanent crisis despite the island's great potential. The major official donors claim that they had left the island to itself since the 2009 crisis. However, World Bank statistics show that, in current terms, Madagascar was receiving US $\$ 400$ million in 1990 and US\$ 500 million in 2013. In the same interval, the Gross National Product (GDP) per capita remained basically the same (equivalent to 440 US\$/capita in 2013). Should COP21 produce a momentum for massive investment in carbon emission reduction and in adaptation to climate change (CC), we propose that, at a minimum, these new projects, plans, programs and policies should aim for sustainability by applying Environmental and Social Assessments at all required levels and that, preferably, this should be the opportunity to approach development differently. In particular, we advocate focusing on enhancing the generative capacity (i.e., the capacity to generate unplanned-for new development options) of Malagasy people to better take advantage of the natural resources and the information and communications technologies (ICT) infrastructure already in place. such an ambitious program is not without risks and pitfalls, but it is one way of thinking about breaking out of Madagascar's current self-reinforcing cycle of under-performance. The purpose of this essay is to question the status quo to stimulate discussion and new thinking, short of which observers, 20 years from now, will find themselves echoing the same frustrations that observers and inhabitants alike experience when faced with the present state of development in Madagascar.
\end{abstract}

\section{RÉSUMÉ}

Au moment où Madagascar, comme tous les pays de cette planète, se prépare à participer à la 21e conférence des Parties (COP21) de la Convention Cadre des Nations Unies sur les Changements Climatiques (CCNUCC), nous considérons les échecs récurrents des politiques de développement à Madagascar pour souligner de possibles biais fondamentaux dans les perceptions des interventions de développement et la transférabilité de solutions, avec, comme résultat, une crise permanente malgré le grand potentiel de l'île. Alors que la plupart des bailleurs de fonds officiels font état d'une cessation de leurs activités dans le pays depuis la crise de 2009, les statistiques de la Banque Mondiale montrent que, en termes courants, Madagascar recevait US $\$ 400$ millions en 1990 et US $\$ 500$ millions en 2013. Au cours de la même période, le Produit intérieur brut par habitant a stagné (équivalent à 440 US\$/capita en 2014). À supposer que la COP21 ait pour résultat des investissements massifs dans la réduction des émissions de carbone et dans I'adaptation au changement climatique, nous proposons que, a minima, ces nouveaux projets, plans, programmes et politiques devraient viser à plus de durabilité en appliquant les Évaluations environnementales et sociales à tous les niveaux requis et que, de préférence, cet afflux de capitaux représente l'opportunité d'une nouvelle approche du développement. En particulier, nous proposons une focalisation sur la capacité générative (définie somme la capacité à générer spontanément de nouvelles options de développement) des citoyens malgaches de mieux tirer parti des ressources naturelles et de l'infrastructure des technologies de l'information et des communications (TIC) déjà en place. L'ambition d'un tel programme n'est ni sans risques ni sans embûches, mais nous estimons qu'il s'agit d'un moyen de sortir du cycle actuel et auto-entretenu de sousperformance qui existe à Madagascar. Cet essai propose ainsi de mettre en cause le statut quo afin de stimuler la discussion et une nouvelle approche. À défaut et sans changement, les habitants comme les observateurs connaitront, dans 20 ans, les frustrations d'aujourd'hui, face à l'état du développement de Madagascar.

\section{INTRODUCTION}

The Conference of Parties of the United Nations Framework Climate Change (CC) Convention (UNFCC), 21st of its kind (COP21) has the primary mandate of being the concluding act of a series of preparatory actions. These actions provide the foundations for a possible historical consensus allowing the Framework to turn into an actual Convention, of the same authority and application as 


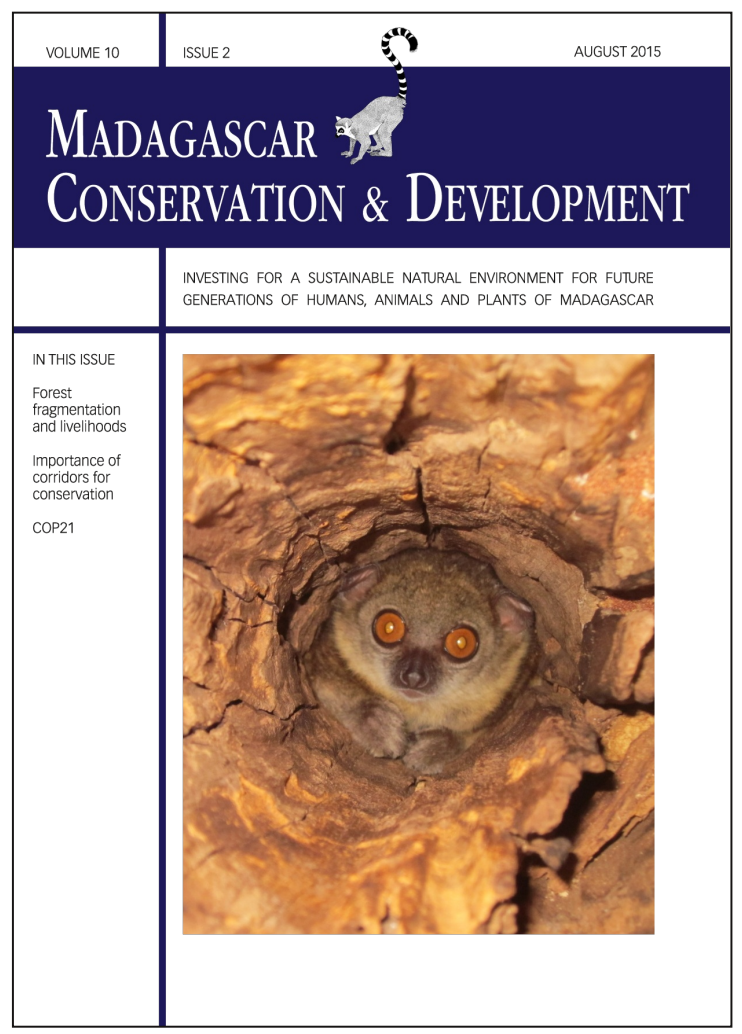

Madagascar Conservation \& Development is the journal of Indian Ocean e-Ink. It is produced under the responsibility of this institution. The views expressed in contributions to MCD are solely those of the authors and not those of the journal editors or the publisher.

All the Issues and articles are freely available at http://www.journalmcd.com

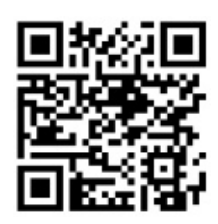

Contact Journal MCD

info@journalmcd.net for general inquiries regarding MCD funding@journalmcd.net to support the journal

Madagascar Conservation \& Development Institute and Museum of Anthropology

University of Zurich

Winterthurerstrasse 190

$\mathrm{CH}-8057$ Zurich

Switzerland

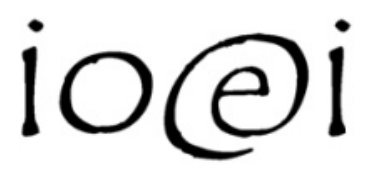

Indian Ocean e-Ink

Promoting African Publishing and Education

www.ioeink.com

Missouri Botanical Garden (MBG)

Madagascar Research and Conservation Program BP 3391

Antananarivo, 101, Madagascar 
the 1992 Convention on Biological Diversity, for instance. COP21 will also be the starting point of intensified efforts by the international community to help stakeholders around the world achieve the targets set and recorded in the preparatory documents. If the Convention is signed and ratified, Madagascar will be responsible for reaching the targets that it will set for itself in its "Intended Nationally Determined Contribution" (INDC), presently under preparation. As of 24 July 2015, very few Sub-Saharan African countries had submitted their INDC. Exceptions were Ethiopia (Federal Democratic Republic of Ethiopia 2015), Benin (République du Bénin 2015) and Kenya (Republic of Kenya 2015). The typical INDC presents a catalogue of activities in various economic sectors along with quantitative and dated targets for carbon emission reductions (CER) and for CC adaptation activities. The 13-page INDC for Ethiopia takes stock of the present annual carbon emission of 150 $\mathrm{Mt}$ of Carbon-Dioxide Equivalent $\left(\mathrm{CO}_{2 \mathrm{e}}\right)$ and offers a program to reduce its 2030 emissions by $64 \%$ compared to the 'Business As Usual' (BAU) scenario. This would be achieved by actions and policies in six sectors/sub-sectors: Agriculture, Forestry, Transport, Electric Power, Industries and Buildings/Urban planning. In the field of adaptation to climate change, pending more research required, the INDC focuses on droughts and floods and gives a key role to farmers and pastoralists, although it touches upon other segments of the population too. It is likely that Madagascar's INDC will contain some or all of Ethiopia's concerns in its upcoming INDC.

In parallel to these country-led efforts, the developed countries are gearing up to establish a massive Green Investment Fund that will ideally consolidate a myriad of existing financing mechanisms with a short-term goal of delivering as much as 100 billion US\$ of financial assistance every year to developing countries. The current scenario is simple: countries prepare and post their INDC, the Convention is signed in December 2015, and money is released to the countries to fund the priority policy reforms, programs, plans and projects described in the INDC. The mandatory monitoring of the implementation of the INDC will also make it a 'live' document. The real overall chain of events may actually be different from this current scenario, but it is generally accepted that large amounts of additional money will flow as a follow-up to COP21, whether the Convention is adopted or not.

The sheer volume of the funds that will be required and requested to fully implement the commitments made in the INDCS is significant and targeted at getting results on the ground. CC policies, plans, programs and projects are far from being environmentally and/or socially neutral (e.g., at the project level, carbon sinks like reforestation may lead to land grab, similarly with large scale solar/wind projects). Consequently, there are few differences between making regular development activities economically viable and environmentally/socially sustainable on the one hand and doing the same with post-COP21 activities on the other hand. The INDCs contain commitments intended to curb carbon emissions and increase adaptation compared to the BAU scenario. Here, we question whether future $\mathrm{CC}$ actions and policies in Madagascar should continue to apply the present approaches to international development (what we call BAU) in this context or whether the shift in development paradigm called for by many should indeed start now, using CC actions and policy reforms as a springboard.

In order to implement its INDC commitment, Madagascar will probably be offered the technical and financial assistance of the international community. The corresponding resources will likely be substantial, and, as such, might have a significant impact on the island's development. Beyond the mechanical aspects of this new potential manna, we question what effects can/will this have on Madagascar's future and does it constitute an opportunity for the island to generate and implement new forms and shapes of development?

\section{CONTEXT}

Madagascar is a global biodiversity hotspot, but its economy, as reflected in its poor overall performance indicators, is far from healthy: it has currently a GDP/capita of around 440 US\$/year, barely above 1 US\$/capita/day, and its Gini Coefficient (a favourite measure of income inequalities at the national level: the higher the coefficient, the "more unequal" the income distribution is) of 44.1 is close to the average in Sub-Saharan Africa. The Human Development Index (HDI), a particularly important composite indicator of demographic and economic data popularised by the UN Development Program (UNDP 2015) of 0.5, ranks Madagascar 155/187 worldwide, just above Zimbabwe. A low HDI, like Madagascar's, and especially a degrading or sluggishly improving HDI can be interpreted as a strong handicap for any form or shape of truly sustainable development. Looking at the distant past (in international development terms), Razafindrakoto et al. (2013) have shown the worsening of economic conditions in the country with an approximate $35 \%$ decrease in the GDP/capita between 1960 and 2008.

In passing, benchmarking Madagascar with Africa may be the usual practice and it is bad enough to see the country in such a low ranking there, but it fares even worse in benchmarking with other islands in the Indian Ocean. If Madagascar has ambitions other than being a laggard in development, it should set its vision and goals on the better performers like Mauritius or the Maldives. Furthermore, whilst the statistical apparatus in Madagascar is almost non-existent, the modest evidence that is available for disaggregating data between the pockets of recent economic growth in the cities and stagnating rural areas is even more disheartening. According to Word Development Indicators (compiled, for instance, at Knoema 2015), poverty in rural areas rose steadily from $78 \%$ in 2001 to $81.2 \%$ in 2010 (latest statistics available) while poverty in urban areas rose from $46 \%$ in 2001 to $55 \%$ in 2005 , but went down to $51 \%$ in 2010.

We propose to visualise Madagascar as a series of nested Russian dolls. There is Madagascar on the planet, with its rich and bright diaspora, its wide and rich Exclusive Economic Zone and its interesting geographical setting and biodiversity features (Rakotomalala 2012, Ganzhorn et al. 2014), there is the island itself, the sixth largest on the planet, and then the actual terrain, with highlands in the centre and lowlands around. At the lowest geographical level, there is a mosaic of extremely diverse landscapes and people, from the community living in quasi-autarchy to the bustling Antananarivo with international standard beach resorts in between. At the individual level, stereotypic of these contrasting life styles would be the 35 year old professional without any dependents in Antananarivo, and the farmer's family on the highlands with 6 to 8 children fighting for their share of the daily rice dish. The geo-spatial dispersion coupled with limited transport infrastructure and cultural heterogeneity also explains why many communities barely have a sense of belonging to a single nation.

Madagascar's economic, social and environmental under- 
performance has generated a series of well-meaning interventions over the years. In the environmental management realm, Madagascar was, worldwide, one of the developing countries that tried, with a strong push from the World Bank, to develop a National Environmental Action Plan (NEAP) (Mercier 2006). Madagascar's NEAP adoption was followed by a series of Environmental Projects that literally cost hundreds of millions of US\$, with some of the millions having to be repaid by Malagasy taxpayers for several decades. For instance, the Environmenta Program II, approved 9 January 1997 and closed 30 June 2003, was funded to the level of US $\$ 110$ million (462 billons Malagasy Francs at the then exchange rate), of which US\$30 million were in the form of an IDA credit (10 year grace period, 40 year repayment, in this case approximately 2007-2036) (World Bank 2003). Reading the ex-post evaluations (World Bank 2003, 2007) of these projects can be salutary for avoiding pitfalls in the design and implementation of future CC-related large scale projects and policy reforms in Madagascar.

\section{OVERVIEW AND CRITIQUE OF INTERVENTIONS: AR- GUING FOR MORE BOTTOM-UP STRATEGIES}

The history of the many and abundant external interventions has given rise to a familiar pattern of relationships where nothing that the interventionists introduce or propose is challenged and nothing that they introduce is challenging. Consequently no strong activist movements are provoked, and the status quo is not threatened. It is not only the international donors and lenders/investors who have this familiar relationship: for organisations like Conservation International (Cl) Madagascar is a lucrative venture, and the development of $\mathrm{Cl}$ and its commercial activities have actually paralleled the Madagascar NEAP and its sequels. The total revenue of $\mathrm{Cl}$ has jumped from US\$ 116 million for fiscal year 2009 to US\$165 million for fiscal year 2014 (Conservation International 2010, 2015). In particular, $\mathrm{Cl}$ has helped create carbon reduction emissions (CERS) for the corridor Ankeniheny-Zahamena. Researchers have established that, on this particular project, conflicts occurred between forest conservation and access to resources affecting local livelihoods (Ratsimbazavy et al 2013). Thus, the $50 \%$ of the CERs going to the local communities include a fair compensation for the negative local impacts of forest conservation.

The present and past interventions in Madagascar as in many other developing countries are all predicated on a flawed superior and arms-length perspective and behavioural script which we can characterise as follows: (i) a failure to recognize the importance of contextual features for the implementation of development agendas, which may be captured as "Madagascar is a developing country like any other and what the international community has made work elsewhere should work in Madagascar"; (ii) a failure to follow through the consequences of failed interventions to examine causal factors: the observation that Madagascar's economic base is not diversified enough and relies too much on the exploitation of natural resources (land and sub-soil) and the primary sector, leads to the premise that attempts should be made, top down, to help that economy to diversify. When these attempts fail, the next round of negotiations and programming will start the wheel spinning again; (iii) assumed inaptitude of the recipients: an assumption that there is nothing political nor cultural about Madagascar's permanent and deepening crisis, just a failure by the Malagasy Government to comply with the advice provided by the
International Monetary Fund (IMF) or the World Bank; (iv) complacency about the expert role of western donors; and ( $V$ ) an amalgam between financial growth on the one hand and sustainable development on the other hand: the fact that the Chinese and others have rolled up their sleeves, circumvented or corrupted further the Government, made direct infrastructure investments and thus helped create some economic growth, should not be misconstrued as sustainable development (Duffy 2007, schuurman and Lowry 2009).

However, because, Madagascar is a system that can be described as a complex network with intertwined social, economic and ecological dimensions, any transplant or graft is unlikely to be totally compatible with the parts/dimensions that are retained. Perhaps an alternative paradigm is called for, and COP21 followup may be the catalyst for its inception.

The Post 2015 High Level Panel (United Nations 2013) has ventured that one key direction the world should take is to put sustainable development at the heart of development and one of the visible effects of this powerful statement is that the 17 or so Sustainable Development Goals will soon replace the 8 Millennium Development Goals adopted by the General assembly of the UN in 2000. Fulfilling peoples' needs in a sustainable manner should be at the heart of the coming development efforts. For Madagascar, harnessing the opportunities created by COP21 and its sequels should include new development dimensions, and, in particular, an emphasis on generative capacity, which the authors define as an effort to innovate using indigenous knowledge and resources co-specialised with requisite external inputs to develop distinctive, locally rooted development trajectories, rather than westerners trying to replace what exists with what they think they know works elsewhere.

Bringing in climate change opens the field for increased activities in all areas, but more particularly in most of the conventional sectorial approaches. What the authors are looking into is the possibility of integrating these sectors at various (and nested) levels of territories or landscapes. This raises the interesting question of the lessons learned from the failures (or in United Nations' terminology the 'limited successes') of past efforts towards Integrated Rural Development (IRD - the 1970s and the 1980s) and of Community Driven Development (CDD, the late 1990s and thereafter). If this integration does not occur, the focus will remain on the promotion of disjoint 'smart' sectorial policies. 'Climate smart agriculture' (CSA) is one of the present buzz words. It is defined in very technical terms by, e.g., targets in terms of the content of organic matter in the soil. CSA may lead to a significant take-off of organic farming. However, many NGOs already question CSA's foundations, seeing in it a Trojan horse for multinationals and other international companies coming in and grabbing the land of family farmers. The Sustainable Agriculture Initiative Platform, for instance, states that "In theory, practices that are unsustainable when looking at them through social, economic or even other (than climate) environmental lenses, could potentially be covered by the term [Climate Smart Agriculture]" (Sustainable Agriculture Initiative 2015). Deciphered in layman's terms, this means that NGOs fear a very negative impact on family farms by applying CSA without effective social and environmental safeguards. Raising these questions may lead to a healthy challenging of indigenous and imported knowledge claims and opens up a debate that goes beyond how to re-arrange the chairs on the Titanic. 


\section{THE BEST OF BAU IN IMPLEMENTING THE FUTURE CC STRATEGIES}

Environmentalists and social scientists have invented and tested tools and methods to marginally improve the way international development is conducted. The major tool to 'green' a project, plan, program or policy is the Environmental and Social Assessment (ESA). Project-level ESA is currently defined as methods and tools used "to identify and assess the potential environmental and social risks and impacts of the proposed project" (World Bank 2015a). Well known and mastered at the project level, Environmental and Social Assessors are now attacking one of economists' strongest fortresses: plans, programs and policies, with the ESA variety known as "Strategic Environmental and Social Assessment" (SESA).

Project-level ESA has permeated and influenced project design and shown successes and failures. The latter include mobilising public involvement too superficially and too late in the project cycle. Successes, however, have included, for the largest projects (mainly in the infrastructure/industry sectors: roads, dams, mining, airports, etc.), the requirement by many financiers of Free, Prior and Informed consent (FPIC) from the affected communities. SESA has a much longer way to go to become mainstreamed, let alone effective. The authors have shown, however, that COP21 sequels, be they in the form of projects, plans, programs and/or policies, should benefit from being subjected to ESA at the relevant levels (Mercier 2010). By balancing economic, environmental and social interests and by providing a platform for the potentially affected populations, ESAs improve the processes, both at the planning and implementing stages. They also provide horizontal (territory, landscape) and vertical (sectors, tiers) linkages. But, as tools at the service of decision makers, ESAs in themselves cannot turn the overall development strategies around and they fall short of correcting the fundamental flaws that lead to the present 'development breakdown' in situations like Madagascar's.

One of the fundamental issues is the way in which the governance of development initiatives drives towards compartmentalisation of effort and outcomes, with large projects predicated on short-term gains. The planned trajectories of such projects are often designed to fulfil donor-specified goals efficiently in a relatively structured fashion with linear progression from one step to next 'move'. However in reality, it is quite possible that as the project advances, new capabilities are developed, new contextual dimensions are perceived and new options are generated for the next move. Attending to this generative capacity for development entails attending to the dynamic nature of evolutionary trajectories and looking for synergies between what exists in the local context and what can be usefully imported from other countries. For example, Kenya's long-drawn journey to establish its Information and Computer Technology (ICT) policy was a failure in terms of meeting the short-term expectations of the World Bank. However, it resulted in the self-organised emergence of a potent local network of public sector champions, entrepreneurial ICT firms, NGOS and civil society (Njihia and Merali 2013). This network embodied the generative capacity which spawned, among other things, the 'invention' of Kenya's pioneering mobile money application (M-pesa) and its rapid uptake and diffusion throughout the country and globally (initially via the diaspora). Whilst the ICT companies were commercially motivated, the societal outcome of this development was rapid penetration of financial services to a rural population that was not served by banks and did not enjoy conventional terrestrial telecommunications, and the ability to make micro payments with mobile money made it viable for the poor to transfer modest funds without incurring prohibitive bank charges.

\section{POSSIBLE PATHS TO FUTURE CC STRATEGIES IN MA- DAGASCAR}

We suggest that a focus on the sustainable use of the island's natural endowments coupled with its significant human and social capital would lead us to investigate further the relationships between the generation and distribution of wealth and the organisation of work in the global, climate-conscious digital economy.

The prevalent vision for growth in the economy of Madagascar is predicated on agricultural production, extracting and exporting minerals, and on tourism. With regard to the first two, given that Madagascar incurs the ecological costs of production of crops and minerals, merely exporting them for integration into the higher end of the value chains situated elsewhere means that it foregoes the opportunity to fully realise its generative capacity. We suggest that Madagascar's comparative advantage of access to natural resources for the generation of renewable (wind, solar and hydro-electric) energy may make local small-processing plants an attractive alternative, both from an ecological perspective and an economic one.

With regard to agriculture- when climate change comes into the equation, it is well worth exploring whether Schumacher's concept of "small is beautiful" (Schumacher 1973) begins to make sense as a viable alternative to large scale monoculture plantations. For example, when we add energy conservation into the equation, it may make sense to deploy modern technologies and smaller scale farming methods with more complete recycling, and local production food and energy for local consumption, possibly with renewables-based energy production driving small cooperative local processing plants. The aspiration of many around the world - developed and developing - is to attain food sovereignty and to have confidence in the provenance and quality of the food they consume, as well as food security: perhaps this is something that should be defended in Madagascar.

Given the advancing affordances of ICTs, it no longer makes sense to be operating a model of economic growth that is predicated on migration of human capital from the countryside to the city - with the production of food distanced from the consumers, and the attendant overheads of packaging and transport. The equivalent of the 'industrial revolution' in Sub-Saharan Africa and island states does not have to follow the trajectory set by history of Western development -it can, at least in part, be predicated on the ICT-based industry of software development and information work, and ICTs can also enable the development of novel, greener business models for the development and delivery of physical goods and services. The potential for deploying ICTs for innovative products, services and business models is demonstrated in Kenya by the emergence of Safaricom and M-pesa to dominate the mobile telephony and mobile money transfer market. If these capabilities are then coupled with ICT-based delivery of education and training, we can begin to see how the investments in CC initiatives, if integrated with human, technological and natural capabilities can realise synergies that may enable Sub-Saharan Africa to leapfrog some of the challenges that the developed nations are currently grappling with. We do not overlook the present lack of generalised access to electricity in Madagascar (only $15 \%$ of Malagasy according to World Bank (2015b)), but half of the population 
now has a portable telephone and the trend is for a continued rapid growth with ad hoc battery charging solutions and portable phones increasingly allowing access to ICT services of the same kind as tablets and computers.

If diversification efforts were focused on the development of capabilities for competing in the digital economy, it may be viable to replace the popular hub-and-spoke model of the city as the locus of wealth management with an intelligent network model. Consistently with Schumacher's vision of using appropriate technologies to empower people, we could conceive a model of local food production and consumption coupled with an ICT industry which has all the benefits for quality of life as 'cottage industry' whilst effectively constituting a large integrated virtual enterprise, with workers based at home or at local community centres with good internet connectivity.

We appreciate that there is a long way to go for Madagascar to come out of the present crisis with more sustainability and equity. However, in terms of building the right set of institutions needed for sustainable development, the Malagasy may not have to look much further than the network of locally managed marine protected areas (Mayol 2013), the rural electrification cooperatives in South America, and the organisations capable of setting up mass demonstrations against land grab in Asia, Africa and elsewhere.

\section{OBSTACLES AND CONSTRAINTS IN MODIFYING THE DEVELOPMENT COURSE IN MADAGASCAR}

Doing away with the sectorial and top-down approaches, all at once, is not without risks, nor will it happen overnight. The key risk is raising too many short term expectations. Changes in development patterns do not happen overnight and are more a series of trial and error. Industry lobbyists and their friends will be quick in pointing out the 'errors' part. Social learning (as recommended in Scherr et al. (2012)) is at the heart of any new development strategy as proposed here. The importance of social networks and discourse is clear for this aspect of development, and for healthy co-evolution across the rugged terrain of stakeholder interests, there needs to be a platform and mechanism for heterogeneous knowledge claims to be visible, challenged and defended topdown and bottom-up. First the 'pipes' need to be in place (in the form of the Internet and mobile phones and their networking infrastructure, etc.), but providing the appropriate information and knowledge flows in the pipes takes time, resources and politica will. These ingredients may turn out to be missing, even if they represent a fraction of the cost of many white elephants, virtual or physical, that can be visited in Madagascar. Passivity from the local populations may contribute to increasing this cost. Since the Malagasy Government has a huge trust and effectiveness handicap to compensate for, there will be the need for vocal and effective pioneers and grassroots organisers. They are probably already around, and some may even be reading this essay.

\section{RECOMMENDATIONS}

It is likely that more funding will be made available to Madagascar as a follow-up to the COP21. Though these funds will be earmarked and processed as CC related, because the actions and policy reforms that will be financed will pertain to many economic sectors, chances are that this opportunity may be treated as being little different from conventional international development assistance and funding. Thus it is recommended that these additional CC funds be treated with extreme care when it comes to sustainability, equity and local empowerment. In particular, ESA for project level and SESA for plans, programmes and CC policies should be the norm. Other sustainability assessment and management/monitoring tools should also be used. The overall objective is to accelerate the path to a green economy and inclusive development putting the local communities in the driver's seat. The technologies exist to build and maintain distributed networks and should be put to general and better use for not only 'smart' individuals, villages, towns and island, but also a more robust and sustainable development at all the levels.

\section{REFERENCES}

Conservation International. 2010. Annual Report 2009. Arlington, VA, USA. Available at <http://www.conservation.org/publications/Documents/Cl_AnnualReport09.pdf>

Conservation International. 2015. Annual Report 2014. Arlington, VA, USA. Available at <http://www.conservation.org/publications/documents/Cl_FY14_AnnualReport.pdf>

Duffy, R. 2007. Gemstone mining in Madagascar. transnational networks, criminalisation and global integration. Journal of Modern African Studies 45, 2 : 185-206. (doi:10.1017/S0022278X07002509)

Federal Democratic Republic of Ethiopia. 2015. Intended Nationally Determined Contribution (INDC) of the Federal Democratic Republic of Ethiopia, UNFCCC. Available at: <http://ow.ly/Q4179>accessed 23 July 2015.

Ganzhorn, J. U., Wilmé, L. and Mercier, J.-L. 2014. Explaining Madagascar's biodiversity. In: Conservation and Environmental Management in Madagascar. I. Scales (ed.), pp 17-43. Routledge, London and New York. (doi:10.13140/2.1.2996.8328)

Knoema. 2015. <http://goo.g//JXKvBF> accessed 5 August 2015.

Mayol, T. L. 2013. Madagascar's nascent locally managed marine area network. Madagascar Conservation \& Development 8, 2: 91-95 (doi:10.4314/mcd.v8i2.8)

Mercier, J.-R. 2006. Madagascar moving towards sustainable development. The preparation of the National Environmental Action Plan (NEAP): Was it a false start? Madagascar Conservation and Development 1, 1: 50-54.

Mercier, J.-R. 2010. Link between Safeguards and Climate Change, Entebbe. Unpub. presentation at an African Development Bank-organised training work shop, AfDB, Ivory Coast. Available at <http://cyberoustal.eu/crbst_6.html>

Njihia, J. M. and Merali, Y. 2013. The bhroader context for ICT4D projects: A morphogenetic analysis. MIS Quarterly 37, 3: 881-906

Rakotomalala, P. 2012. Implicites de la crise 2009 et diplomatie française. In: Madagascar, le Coup d’État de Mars 2009. S. Randrianja (ed.), pp 211-238. Éditions Karthala, Paris.

Ratsimbazafy, L. C., Harada, K. and Yamamura, M. 2013. Forest conservation and livelihood conflict in REDD: A case study from the corridor Ankeniheny Zahamena REDD project, Madagascar. International Journal of Biodiversity and Conservation 3, 12: 618-630.

Razafindrakoto, M., Roubaud, F. and Wachsberger, J. M. 2013. Institutions, gouvernance et croissance de long terme à Madagascar: l'énigme et le paradoxe. Document de travail Institut de Recherches sur le Développement (IRD), Paris. Available at <www.dial.ird.fr>

Republic of Kenya. 2015. Ministry of Environment and Natural Resources, July 2015, Kenya's Intended National Determined Contribution, Nairobi, Kenya. Available at <http://www4.unfccc.int/submissions/indc/Submission\%20Pages/submissions.aspx>

République du Bénin. 2015. Ministère de I'Environnement, Août 2015, Contributions Prévues Déterminées au Niveau National (CPDN), Porto Novo, Bénin. Available at http://www4.unfccc.int/submissions/indc/Submis sion\%20Pages/submissions.aspx>

Scherr, S. J., Shames, S. and Friedman, R. 2012. From climate-smart agriculture to climate-smart landscapes. Agriculture and Food Security 1: \#12. (doi:10.1186/2048-7010-1-12) 
Schumacher, E. F. 1973, Small is Beautiful: A Study of Economics as if People Mattered. Blond and Briggs, London, UK.

Schuurman, D. and Lowry II, P. P. 2009, The Madagascar rosewood massacre. Madagascar Conservation \& Development 2, 4: 98-102. (doi:10.4314/mcd.v4i2.48649)

Sustainable Agriculture Initiative. 2015. Position paper on Climate Smart Agriculture. Downloaded from <http://ow.ly/Q4kOH> 23 July 2015.

United Nations. 2013. A New Global Partnership to Eradicate Poverty and Transform Economies through Sustainable Development. The Report of the HighLevel Panel of Eminent Persons on the Post-2015 Development Agenda. United Nations Publication, New York, USA.

United Nations Development Program. 2015. Human Development Index (HDI). Available at Available at <http://ow.ly/RpTJB>

World Bank. 2003. Implementation Completion Report on a Credit in the Amount of US\$30 Million to Madagascar for the Environment Program Phase II Project. The World Bank, Washington DC. Downloaded from <http://ow.ly/Q4|4V> 23 July 2015.

World Bank. 2007. Projet Performance Assessment Report Madagascar Environment II, The Independent Evaluation Group, World Bank, Washington DC Downloaded from <http://ow.ly/Q4|3h> 23 July 2015.

World Bank. 2015a. Environmental and Social Standard 1. Assessment and Management of Environmental and Social Risks and Impacts. Second draft for consultation, World Bank, Washington DC.

World Bank. 2015b. <http://donnees.banquemondiale.org/indicateur/EG.ELC.ACCS.ZS> accessed 10 July 2015. 